\title{
The Michael Reaction of Enaminones with $N$-(p-tolyl)-maleimide: Synthesis and Structural Analysis of Succinimide-enaminones
}

\author{
Silvio Cunha ${ }^{*, \#, a}$, Waléria Rodovalho ${ }^{a}$, Neucírio R. Azevedo ${ }^{a}$, Marcos de O. Mendonça ${ }^{b}$, \\ Carlito Lariucci ${ }^{b}$ and Ivo Vencato
}

\author{
${ }^{a}$ Instituto de Química, ${ }^{b}$ Instituto de Física, Universidade Federal de Goiás, CP 131, 74001-970 Goiânia - GO, Brazil
}

\begin{abstract}
Succinimido enaminonas foram sintetizadas através da reação de enaminonas e a $N$-( $p$-toluil)maleimida em rendimento moderado a bom. A ação antibacteriana destes compostos contra $E$. coli $\mathrm{e}$ S. aureus foi avaliada, mas a atividade antibacteriana não foi significativa. A regioquímica das succinimido enaminonas foi racionalizada empregando-se a teoria dos orbitais moleculares de fronteira. A estrutura cristalina de um dos compostos foi determinada e foram observadas várias pontes de hidrogênio inter- e intramolecular do tipo $\mathrm{NH}$...O e CH...O.
\end{abstract}

The reaction of $N$-(p-tolyl)-maleimide with enaminones afforded succinimide-containing enaminones in moderate to good yields, and these compounds were evaluated against $E$. coli and $S$. aureus, but no significant antibacterial activity was observed. The regiochemistry of the compounds was examined mechanistically within frontier molecular orbital considerations. In the solid state three-dimensional structure there is the formation of cooperative inter- and intramolecular $\mathrm{NH} . . \mathrm{O}$ and $\mathrm{CH}$...O hydrogen bonding.

Keywords: enaminones, succinimide, maleimide

\section{Introduction}

Over the years, the Michael addition of enaminones has been intensively studied and many synthetic achievements were described. ${ }^{1}$ For instance, the stereocontrolled elaboration of quaternary carbon centers followed by the aza-annulation of enaminones has been used in the synthesis of many nitrogen-containing compounds, where the Michael addition was the key step. ${ }^{2}$ Among the Michael acceptors studied (e.g. nitroolefins ${ }^{3}$ maleic anhydrides $\left.{ }^{4}\right)$ the maleimides have the most complex reaction pattern, highly dependent of the nitrogen substituents at the maleimides and at the enaminones, Scheme $1 .^{5}$

Additionally to the complex behavior, this kind of reaction caught our attention due its potential in the synthesis of succinimide-containing enaminones derivatives such as $4 .^{5}$ The antibacterial activity of fivemembered imides is well documented and some structural modifications to improve this one, such as the presence of $N$-aryl groups have been suggested. ${ }^{6}$ As part of our recent

\footnotetext{
* e-mail: silviodc@ufba.br

* Present address: Instituto de Química, Universidade Federal da Bahia, Campus de Ondina, 40170-290 Salvador-BA, Brazil
}

research program aimed at the synthesis of biological active substances ${ }^{7}$ such as anticonvulsant and antibacterial compounds and to provide insight into the reactivity of enaminones toward $N$-aryl-maleimides, we decided to study the Michael reaction of enaminones with $N$-( $p$-tolyl)maleimide, in search for a general method to the synthesis of $N$-aryl-succinimide-containing enaminones. Although Michael addition of enaminones with $\mathrm{N}-\mathrm{H}$ and $\mathrm{N}$-alkylmaleimides had been described three decades ago, studies with $N$-aryl maleimides are scarce. ${ }^{5}$ Afterward, to the best of our knowledge, there are no structural and biological studies with succinimide-enaminones derivatives.

\section{Results and Discussion}

$N$-(p-tolyl)-maleimide reacted smoothly with enaminones $\mathbf{6 a - c}$ in benzene under reflux. Crystalline solids were isolated and these materials were 1:1 adduct as indicated by mass spectrum and proton NMR integration. The formation of a succinimide-enaminone was proposed by comparison of spectral data with model compounds 3 and 4. ${ }^{5}$ Although these reported compounds present similar IR and ${ }^{1} \mathrm{H}$ NMR spectra, their ${ }^{13} \mathrm{C}$ NMR show significant differences. Thus, the chemical shifts of the $\alpha$ and $\beta$ carbons 
<smiles>[R]N/C(=C/C(=O)c1ccccc1)S(=O)[R]([R])[R]([R])=C</smiles>

5

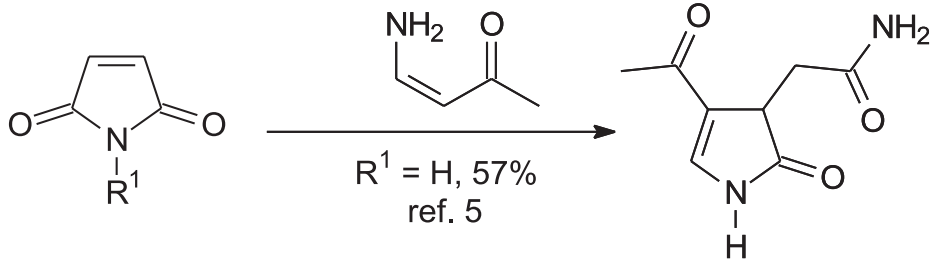

1 ref. 5

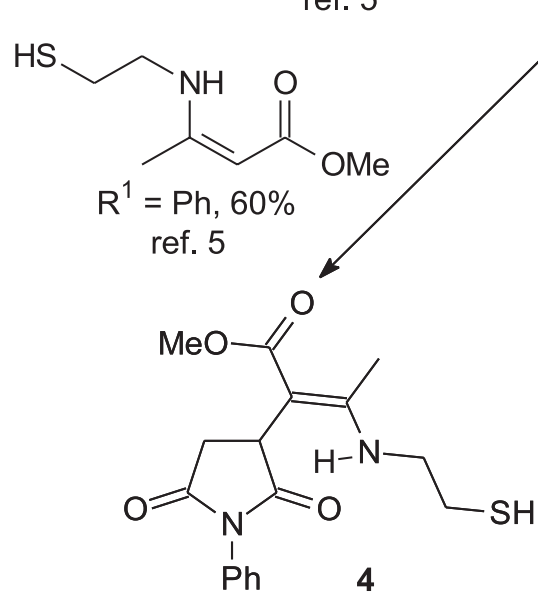

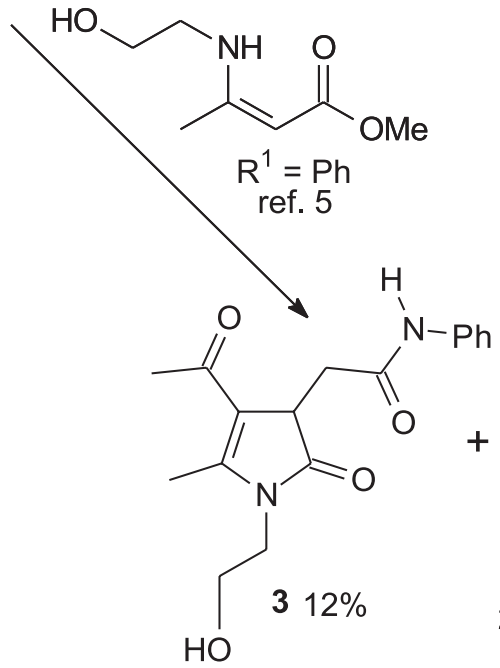

Scheme 1.

relative to the carbonyl group of the enaminone moiety are $106.4 \mathrm{ppm}$ and $154.8 \mathrm{ppm}$ for $\mathbf{3}$, while for $\mathbf{4}$ they appear at $90.0 \mathrm{ppm}$ and $161.3 \mathrm{ppm}$, respectively. ${ }^{5}$ In the adducts here obtained, the ${ }^{13} \mathrm{C}$ chemical shifts of $\mathrm{C} \alpha$ and $\mathrm{C} \beta$ are in agreement with structure $\mathbf{8}$ analogous to $\mathbf{4}$ (see Experimental), Scheme 2. The ${ }^{1} \mathrm{H}$ NMR spectra contained a low field N-H (8.64-9.94 ppm) which suggests its participation in intramolecular hydrogen bonding. Despite the reportedly obtained $E$ configuration to the model compound $4,{ }^{5}$ we assigned the $Z$ configuration to 8 because $E$ - and Z-configurational isomers of enaminones are well distinguished by typical N-H chemical shifts ( $E$-isomer: 4.1 6.5 ppm; Z-isomer: $9.5-12.0 \mathrm{ppm}) .{ }^{8}$ Moreover, the structure of the addition products $8 \mathbf{a}$ was unambiguously confirmed by $\mathrm{X}$-ray analysis and the $Z$ configuration corroborated, as shown in Figure 1. This reaction proved to be sensitive to $N$-acyl substitution in $\mathbf{6}$. While moderated to good yields were obtained with enaminones $\mathbf{6 a - c}, N$-( $p$-tolyl)-maleimide failed to react with enaminone $\mathbf{6 d}$ under the condition employed, even at prologated heating, Scheme 2.

The formation of 8a-c may be visualized as occurring by reaction of the enaminone-C $\alpha$ at the electrophilic C-3 of the $N$-( $p$-tolyl)-maleimide, followed by proton transfer. However, at this point it is not clear the controlling factors that modulate maleimide and enaminone reactivity to form succinimide-enaminones or other nucleus present in

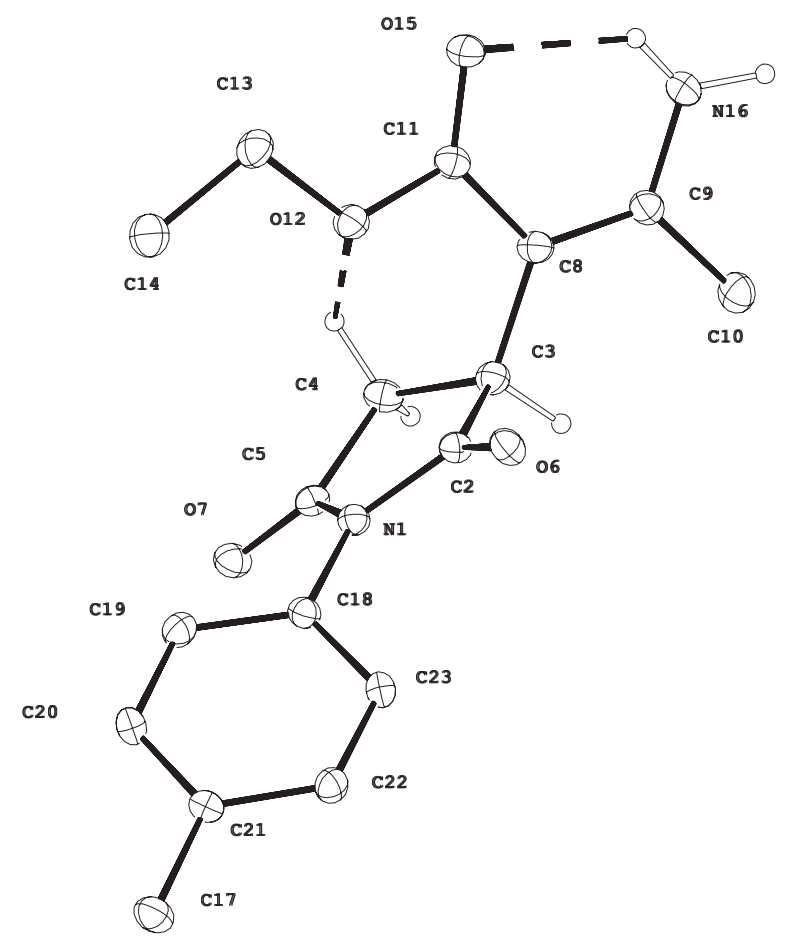

Figure 1. X-ray crystallographic structure of molecule 1 of compound 8a. Displacement ellipsoids are shown at the $30 \%$ probability level. Only the $\mathrm{H}$-atoms involved in $\mathrm{H}$-bonds are shown with arbitrary size. Two intramolecular H-bonds are shown with broken lines. 


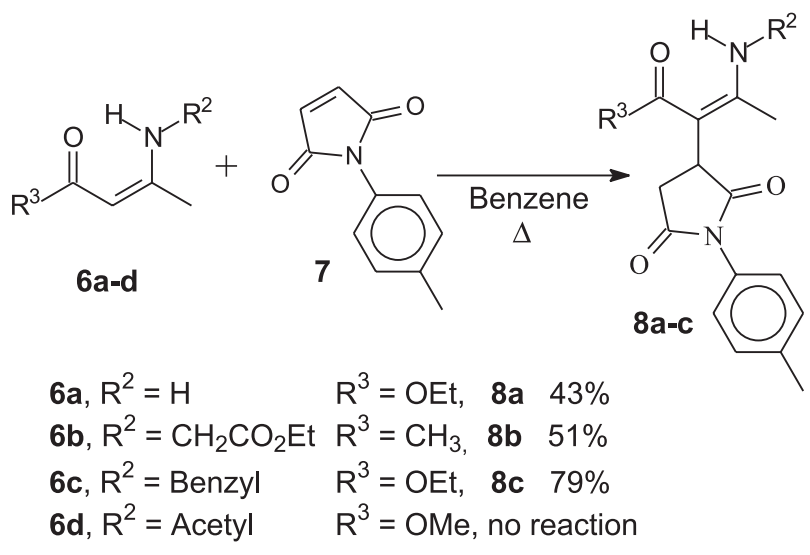

Scheme 2.

Schemes 1 and 2. With the objective of shedding new light on this question we undertook a frontier orbital treatment in combination with the hardness-softness concept. Electronic parameters of model maleimides and enaminones were calculated using the AM1 method, ${ }^{9}$ as implemented in the MOPAC 6.0 package, ${ }^{10}$ and are shown in Table 1. According to Parr-Pearson principle of absolute hardness, ${ }^{11} N$-(p-tolyl)-maleimide is softer than $N$-H and $\mathrm{N}$-alkyl maleimides because of the smaller HOMO-LUMO energy gap. Thus, it would appear that reaction of soft enaminones and $\mathrm{N}$-aryl maleimides is kinetically favored, and frontier orbital control, and not charge control, should govern the process. In this way, an attack of enaminone$\mathrm{C} \alpha$ at the $N$-(p-tolyl)-maleimide-C3, wherein the largest frontier orbital coefficients are located (see Table 1), results in the regiochemistry observed in Scheme 2.

To unambiguously assign the structure of the obtained succinimide-enaminones and to gain insight into intramolecular and intermolecular interactions the crystal structure of $\mathbf{8 a}$ was determined, and several structural features emerged. The asymmetric unit has two independent molecules. As noted in Figure 1, which shows the unprimed molecule with labeled atoms, strong hydrogen bonding occurs between the carbonyl oxygen and the $\mathrm{NH}$ group (intramolecular hydrogen bond: N16-H16A...O15 [2.699(3)


six-membered ring. In addition, a weak $\mathrm{CH}$... intramolecular H-bond was also observed: C4-

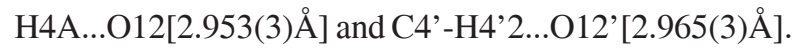

Figure 2 shows the observed intermolecular NH...O

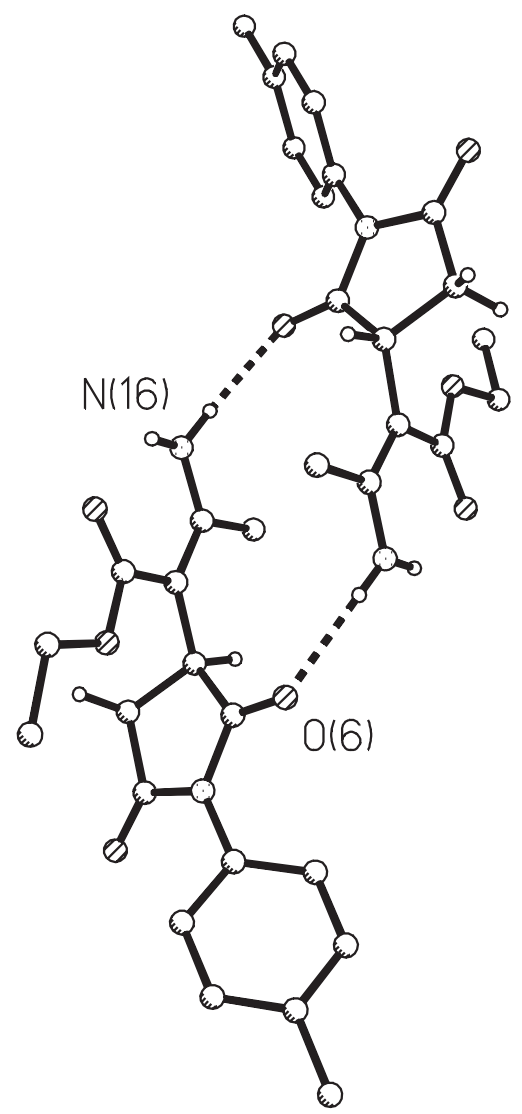

Figure 2. Intermolecular H-bonds between independent molecules 1 and 2 of $8 \mathbf{a}$.

Table 1. Electronic parameters calculated by AM1 method for maleimides and enaminones

\begin{tabular}{|c|c|c|c|c|c|c|c|c|c|c|}
\hline \multirow[b]{2}{*}{ Maleimide or Enaminone } & \multirow[b]{2}{*}{$\eta^{\mathrm{a}}$} & \multicolumn{2}{|c|}{ Energy $(\mathrm{eV})$} & \multicolumn{2}{|c|}{ HOMO Coefficients } & \multirow{2}{*}{$\begin{array}{r}\text { LUMO } \\
\mathrm{C} 2\end{array}$} & \multirow{2}{*}{$\frac{\text { Coefficients }}{\text { C3 }}$} & \multicolumn{3}{|c|}{ Charge } \\
\hline & & HOMO & LUMO & $\mathrm{C} 3$ & $\mathrm{~N}$ & & & $\mathrm{C} 2$ & $\mathrm{C} 3$ & $\mathrm{~N}$ \\
\hline $\mathrm{R}^{1}=\mathrm{H}$ & 5.03 & -11.27 & -1.21 & - & - & 0.354 & $4 \quad 0.522$ & 0.33 & -0.15 & - \\
\hline $\mathrm{R}^{1}=\mathrm{CH}_{3}$ & 4.68 & -10.51 & -1.14 & - & - & 0.354 & $4 \quad 0.522$ & 0.33 & -0.15 & - \\
\hline $\mathrm{R}^{1}=p$-tolyl & 3.85 & -8.92 & -1.22 & - & - & 0.354 & $4 \quad 0.521$ & 0.33 & -0.15 & - \\
\hline $\mathrm{R}^{2}=\mathrm{PhCH}_{2}, \mathrm{R}^{3}=\mathrm{CH}_{3}$ & 4.45 & -8.73 & 0.18 & 0.672 & 0.537 & - & - & - & -0.39 & -0.30 \\
\hline $\mathrm{R}^{2}=\mathrm{R}^{3}=\mathrm{H}$ & 4.15 & -8.74 & 0.44 & 0.710 & 0.539 & - & - & - & -0.41 & -0.37 \\
\hline
\end{tabular}

${ }^{a}$ Absolute hardness. ${ }^{11}$ 
hydrogen bonds between molecules 1 and 2 of 8a: N16H16B...O6' [x, 1+y, z, 2.968(3) A], N16'-H16D...O6 [x, y$1, \mathrm{z}, 2.988(3) \AA]$. Molecule 1 of $\mathbf{8 a}$ is involved in a CH...O $\mathrm{H}$-bond with another one due to an inversion symmetry operation: C3-H3...O7[1-x, 1-y, -z, 3.199(3) ̊], as indicated in Figure 3, leading to a structural feature like a dimer through this intermolecular interaction. This kind of interaction and its influence in the conformation was recently described. ${ }^{12}$

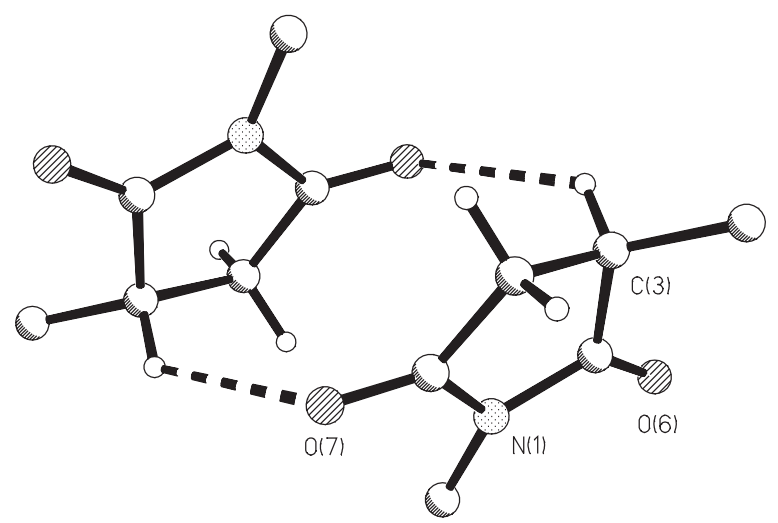

Figure 3. Intermolecular C-H...O interactions around an inversion center. Only the succinimide rings are shown for clarity.

The molecules present small differences in the torsion angles O15-C11-C8-C3 of -173.1(2) and 170.6(2), O15C11-C8-C9 of 4.0(4) and -9.3(4), O15-C11-O12-C13 of $4.0(3)$ and $-6.1(3)^{0}$ for the unprimed and primed molecules, respectively. The five-membered imide rings are twisted on $\mathrm{C} 3-\mathrm{C} 4$ bond, with some distortions as can be seen from the Cremer and Pople ${ }^{13}$ parameters: $\mathrm{N} 1 \rightarrow \mathrm{C} 2 \rightarrow \ldots \mathrm{C} 5[\mathrm{Q}=$ $\left.0.162(3) \AA, \phi=94.1(8)^{\circ} ; \mathrm{Q}=0.151(2) \AA, \phi=266.4(8)^{\circ}\right]$ for the unprimed and primed molecules, respectively. The $\mathrm{O} 7$ atom is $0.13(4) \AA$ from the least-square plane through the atoms C2 N1 C5 C4 and the O7' atom is only 0.05(4) from the corresponding primed plane. Therefore, the intermolecular hydrogen bond where $\mathrm{O} 7$ is involved is also related to the twisting on $\mathrm{C} 3-\mathrm{C} 4$ bond. In the unprimed and primed molecules of $\mathbf{8 a}$, no pyramidalization of the imide nitrogen $\mathrm{N}(1)$ was observed, with the sum of the angles at $\mathrm{N}(1)$ of 359.7 and $360.0^{\circ}$, respectively.

The antibacterial activity of succinimide-enaminones 8a-c was evaluated against Escherichia coli ATCC 8739 (gram-negative) and Staphilococus aureus ATCC 6538 (gram-positive), and the minimal inhibitory concentration (MIC) was determined. However, no activity was observed to compounds 8a-c even at $1000 \mathrm{mg} \mathrm{mL}^{-1}$. Efforts are underway to elucidate the structural-activity relationship that can improve the antibacterial activity of succinimideenaminones derivatives.

\section{Experimental}

Melting points were determined on a Karl Kolb apparatus and are uncorrected. Infrared spectra were recorded as $\mathrm{KBr}$ discs on a FT-IR BOMEM MB100 instrument. NMR spectra were obtained for ${ }^{1} \mathrm{H}$ at $300 \mathrm{MHz}$ and for ${ }^{13} \mathrm{C}$ at $75 \mathrm{MHz}$ using a Varian Gemini 300 or a Bruker AC300P spectrometers at Instituto de Química/UNICAMP. Chemical shifts are reported in ppm units downfield from reference (internal TMS). MS spectra were measured on a SHIMADSU CG-MS QP-5050 spectrometer at $70 \mathrm{eV}$. Elemental analyses were performed on a $2400 \mathrm{CHN}$ Perkin Elmer instrument at Instituto de Química/UNICAMP. The single crystal X-ray data collection was done with a Nonius CAD-4 diffractometer at Instituto de Física-SC/USP. Enaminones $\mathbf{6 a}, \mathbf{6 b}, \mathbf{6 c}, \mathbf{6 d}$ and $N$-( $p$-tolyl)-maleimide were prepared according to known procedures. ${ }^{14}$

Ethyl (Z)-3-amino-2-[1-(4-methylphenyl)-2,5-dioxo-2,5dihydro-1H-3-azolyl]-2-butenoate (8a). A solution of 393.0 $\mathrm{mg}(3.0 \mathrm{mmol})$ of enaminone $\mathbf{6 a}$ and $597.0 \mathrm{mg}(3.0 \mathrm{mmol})$ of $N$-(p-tolyl)-maleimide 7 in $10 \mathrm{~cm}^{3}$ of benzene was heated at reflux for 1 day (the solution turned yellow and a precipitate began to form after $30 \mathrm{~min}$.), after which time the reaction mixture was cooled at room temperature, and the solvent was evaporated. The residue was recrystallized from $\mathrm{CH}_{2} \mathrm{Cl}_{2}$ /petroleum ether to give $433.8 \mathrm{mg}(43 \%)$ of $\mathbf{8 a}$ as colorless solid, mp $178-179{ }^{\circ} \mathrm{C}$. IR (KBr) $v_{\max } / \mathrm{cm}^{-1} 3407$, 1772, 1702, 1666, 1620, 1378, 1172. ${ }^{1} \mathrm{H}$ NMR $\left(\mathrm{CDCl}_{3}\right)$ : $1.18(3 \mathrm{H}, \mathrm{t}, J 7.1 \mathrm{~Hz}) ; 2.09(3 \mathrm{H}, \mathrm{s}) ; 2.38(3 \mathrm{H}, \mathrm{s}) ; 2.77$ (1H, dd, $J 18.3$ and $J 5.5 \mathrm{~Hz}$ ); 3.04 (1H, dd, $J 18.3$ and $J 9.5 \mathrm{~Hz}) ; 3.76$ (1H, dd, $J 9.5$ and $J 5.5 \mathrm{~Hz}) ; 4.14(2 \mathrm{H}, \mathrm{m}) ; 4.88(1 \mathrm{H}, \mathrm{sl}) ; 7.19$ $(2 \mathrm{H}, \mathrm{d}, J 8.1 \mathrm{~Hz}) ; 7.28(2 \mathrm{H}, \mathrm{d}, J 8.1 \mathrm{~Hz}) ; 8.64(1 \mathrm{H}, \mathrm{sl}) .{ }^{13} \mathrm{C}$ NMR $\left(\mathrm{CDCl}_{3}\right): 14.3\left(\mathrm{CH}_{3}\right) ; 21.1\left(\mathrm{CH}_{3}\right) ; 21.4\left(\mathrm{CH}_{3}\right) ; 36.1$ $\left(\mathrm{CH}_{2}\right) ; 39.7(\mathrm{CH}) ; 59.5\left(\mathrm{CH}_{2}\right) ; 90.6(\mathrm{C}) ; 126.1(\mathrm{CH}) ; 129.8$ (CH); $138.4(\mathrm{C}) ; 159.6(\mathrm{C}) ; 168.4(\mathrm{C}) ; 176.3$ (C); 179.1 (C). MS, $m / z$ (\%): 318 (1.5) [M+ +2], $317(11)\left[\mathrm{M}^{+}+1\right], 316(52)$ $\left[\mathrm{M}^{+}\right], 209$ (23), 181 (100), 126 (26), 107 (85), 81 (41). Anal. Calcd. for $\mathrm{C}_{17} \mathrm{H}_{20} \mathrm{~N}_{2} \mathrm{O}_{4}$ : C, 64.56\%; H, 6.33\%; N, 8.86\%. Found: C, 64.32\%; H, 6.21\%; N, 8.73\%.

Ethyl 2-(Z)-1-methyl-2-[1-(4-methylphenyl)-2,5-dioxo2,5-dihydro-1H-3-azolyl]-3-oxo-1-butenylaminoacetate $(8 \boldsymbol{b})$. A solution of $206.3 \mathrm{mg}(1.1 \mathrm{mmol})$ of enaminone $\mathbf{6 b}$ and $211.2 \mathrm{mg}$ (1.1 mmol) of $N$-( $p$-tolyl)-maleimide 7 in 10 $\mathrm{cm}^{3}$ of benzene was heated at reflux for $12 \mathrm{~h}$, after which time the reaction mixture was cooled at room temperature, and the solvent was evaporated. The residue was recrystallized from $\mathrm{CH}_{2} \mathrm{Cl}_{2}$ /petroleum ether and the solid that formed was triturated with ethyl ether to give 214.3 $\mathrm{mg}(51 \%)$ of $\mathbf{8 b}$ as yellow solid, mp $127-130^{\circ} \mathrm{C}$. IR (KBr) $v_{\max } / \mathrm{cm}^{-1} 3345,1735,1658,1602,1386,1226 .{ }^{1} \mathrm{H} \mathrm{NMR}$ (Acetone-D $): 1.28(3 \mathrm{H}, \mathrm{t}, J 7.0 \mathrm{~Hz}) ; 2.26(3 \mathrm{H}, \mathrm{s}) ; 2.31(3 \mathrm{H}$, 
s); $2.40(3 \mathrm{H}, \mathrm{s}) 3.01(2 \mathrm{H}, \mathrm{m}) ; 3.71(1 \mathrm{H}, \mathrm{m}) ; 4.21(2 \mathrm{H}, \mathrm{q}, J$ $7.0 \mathrm{~Hz}) ; 4.32(1 \mathrm{H}, \mathrm{d}, J 17.9 \mathrm{~Hz}) ; 4.53(1 \mathrm{H}, \mathrm{d}, J 17.9 \mathrm{~Hz})$; $7.05(2 \mathrm{H}, \mathrm{d}, J 8.1 \mathrm{~Hz}) ; 7.42(2 \mathrm{H}, \mathrm{d}, J 8.1 \mathrm{~Hz}) ; 9.01(1 \mathrm{H}, \mathrm{sl})$. ${ }^{13} \mathrm{C} \mathrm{NMR}$ (Acetone- $\left.\mathrm{D}_{6}\right): 12.0\left(\mathrm{CH}_{3}\right) ; 13.0\left(\mathrm{CH}_{3}\right) ; 19.8\left(\mathrm{CH}_{3}\right)$; $36.1\left(\mathrm{CH}_{2}\right) ; 40.4(\mathrm{CH}) ; 42.6\left(\mathrm{CH}_{2}\right) ; 60.4\left(\mathrm{CH}_{2}\right) ; 95.3(\mathrm{C})$; $116.2(\mathrm{C}) ; 118.8(\mathrm{CH}) ; 128.3(\mathrm{CH}) ; 131.7(\mathrm{C}) ; 135.7(\mathrm{C})$; 151.8 (C); 167.2 (C); 177.0 (C); 191.6 (C). MS, m/z (\%): $374(1.4)\left[\mathrm{M}^{+}+2\right], 373(7.3)\left[\mathrm{M}^{+}+1\right], 372(30)\left[\mathrm{M}^{+}\right], 265$ (19), 237 (79), 192 (41), 163 (26), 150 (19), 136 (23), 122 (22), 107 (100). Anal. Calcd. for $\mathrm{C}_{20} \mathrm{H}_{24} \mathrm{~N}_{2} \mathrm{O}_{5} \mathrm{C}, 64.52 \% ; \mathrm{H}$, $6.45 \%$; N, 7.53\%. Found: C, 64.81\%; H, 6.66\%; N, 7.28\%.

Ethyl (Z)-3-benzylamino-2-[1-(4-methylphenyl)-2,5dioxo-2,5-dihydro-1H-3-azolyl]-2-butenoate $(8 \mathrm{c})$. A solution of $209.1 \mathrm{mg}(1.0 \mathrm{mmol})$ of enaminone $\mathbf{6 c}$ and $182.8 \mathrm{mg}$ ( $1.0 \mathrm{mmol})$ of $N$-(p-tolyl)-maleimide 7 in $10 \mathrm{~cm}^{3}$ of benzene was heated at reflux for $12 \mathrm{~h}$, after which time the reaction mixture was cooled at room temperature, and the solvent was evaporated. The residue was triturated with ethyl ether to give $320.7 \mathrm{mg}(79 \%)$ of $\mathbf{8 c}$ as colorless solid, $\mathrm{mp} 108-110^{\circ} \mathrm{C}$. IR (KBr) $v_{\max } / \mathrm{cm}^{-1} 3463,1776,1699,1654$, 1383, 1183. ${ }^{1} \mathrm{H}$ NMR (Acetone- $\left.\mathrm{D}_{6}\right): 1.15(3 \mathrm{H}, \mathrm{t}, J 7.0 \mathrm{~Hz})$; $2.16(3 \mathrm{H}, \mathrm{s}) ; 2.37(3 \mathrm{H}, \mathrm{s}) ; 2.68(1 \mathrm{H}, \mathrm{dd}, J 17.7$ and $J 5.7$ $\mathrm{Hz}) ; 3.09(1 \mathrm{H}$, dd, $J 17.7$ and $J 9.7 \mathrm{~Hz}) ; 4.05(2 \mathrm{H}, \mathrm{m}) ; 4.15$ $(1 \mathrm{H}, \mathrm{m}) ; 4.57(2 \mathrm{H}, \mathrm{s}) ; 7.19(2 \mathrm{H}, \mathrm{d}, J 7.9 \mathrm{~Hz}) ; 7.26(2 \mathrm{H}, \mathrm{d}, J$ $7.9 \mathrm{~Hz}) ; 7.35(5 \mathrm{H}, \mathrm{m}) ; 9.94(1 \mathrm{H}, \mathrm{sl}) .{ }^{13} \mathrm{C}$ NMR (Acetone$\left.\mathrm{D}_{6}\right): 13.2\left(\mathrm{CH}_{3}\right) ; 14.0\left(\mathrm{CH}_{3}\right) ; 19.6\left(\mathrm{CH}_{3}\right) ; 35.5\left(\mathrm{CH}_{2}\right) ; 39.0$ $(\mathrm{CH}) ; 46.1\left(\mathrm{CH}_{2}\right) ; 57.8\left(\mathrm{CH}_{2}\right) ; 88.9(\mathrm{C}) ; 125.3(\mathrm{CH}) ; 126.0$ $(\mathrm{CH}) ; 126.3(\mathrm{C}) ; 127.8(\mathrm{CH}) ; 128.3(\mathrm{CH}) ; 129.6(\mathrm{C}) ; 136.6$ (C); 137.9 (C); 160.9 (C); 167.7 (C); 174.8 (C); 178.0 (C). MS, $m / z$ (\%): 286 (100), 257 (21), 239 (19), 119 (59). Anal. Calcd. for $\mathrm{C}_{24} \mathrm{H}_{26} \mathrm{~N}_{2} \mathrm{O}_{4}$ : C, 59.11\%; H, 6.40\%; N, 6.90\%. Found: C, $59.01 \%$; H, 6.47\%; N, 6.88\%.

Crystal structure of $8 a . \mathrm{C}_{17} \mathrm{H}_{20} \mathrm{~N}_{2} \mathrm{O}_{4}, \mathrm{M}_{\mathrm{w}}=316.35$, monoclinic, space group $\mathrm{P} 2_{1} / \mathrm{c}, \mathrm{Z}=8, \mathrm{a}=14.708(3), \mathrm{b}=$ 9.561(2), $\mathrm{c}=23.155(5) \AA, \beta=98.02(3)^{0}, \mathrm{~V}=3224.3(12) \AA^{3}$, $\mathrm{d}_{\mathrm{c}}=1.303 \mathrm{Mg} \mathrm{m}^{-3}, \lambda(\mathrm{Mo} \mathrm{K} \alpha)=0.71073 \AA, \mathrm{m}=0.094 \mathrm{~mm}^{-1}$, 70552 measured reflections, 5687 unique $\left(\mathrm{R}_{\text {int }}=0.105\right)$ of which 4270 were considered as observed with $\mathrm{I}>2 \sigma(\mathrm{I})$. The single crystals were obtained by diffusion of petroleum ether into a solution of synthesized succinimide-enaminone $\mathbf{8 a}$ in $\mathrm{CH}_{2} \mathrm{Cl}_{2}$ at room temperature. The structure was solved with direct methods using SHELXS97 ${ }^{15}$ and it was refined anisotropically with full-matrix least-squares on $\mathrm{F}^{2}$ using SHELXL97. ${ }^{16}$ The hydrogen atoms were placed at calculated position except those involved in H-bonds, found on difference maps and refined. Final indices: $\mathrm{R}_{1}\left(\mathrm{~F}_{\mathrm{o}}\right)=0.054$, $\mathrm{wR}_{2}\left(\mathrm{~F}^{2}\right)=0.146$ for 434 refined parameters.

Crystallographic data (excluding structure factors) for the structures in this paper have been deposited with the Cambridge Crystallographic Data Centre as supplementary publication number CCDC 173681. Copies of the data can be obtained, free of charge via www.ccdc.cam.ac.uk/ conts/retrieving.html (or from the Cambridge Crystallographic Data Centre, CCDC, 12 Union Road, Cambridge CB2 1EZ, UK ; fax: +44 1223336033 ; or email: deposit@ccdc.cam.ac.uk).

Antibacterial assay. The bacterias used in this experiment were Escherichia coli ATCC 8739 (gramnegative) and Staphilococus aureus ATCC 6538 (grampositive). Antibacterial activity was measured using a dilution in agar technique. ${ }^{17}$ The compounds $(20 \mathrm{mg}$ ) were solubilized in $1 \mathrm{~mL}$ of dimethyl sulfoxide (DMSO) and serially two-fold diluted in nutrient agar (peptone, beef extract and agar), to obtain a concentration range of 62.5$1000 \mu \mathrm{g} \mathrm{mL}^{-1}$. The control was plates of nutrient agar containing only DMSO diluted in the same way, which did not influence the bacterial growth. The bacterias from broth medium were suspended in sterile physiological Tris buffer ( $\mathrm{pH} 7.4,0.05 \mathrm{~mol} \mathrm{~mL}^{-1}$ ), homogenised and adjusted to an OD $\left(530 \mathrm{~nm}\right.$ ) of 0.05 (equivalent to $1 \mathrm{X} 10^{6} \mathrm{UFC} \mathrm{mL}^{-1}$ ). This suspension $(3 \mu \mathrm{L})$ was inoculated using an automatic micropippete for the test in the agar plates (diameter: $10 \mathrm{~cm}$ ). The plates were incubated at $37^{\circ} \mathrm{C}$ for $24 \mathrm{~h}$. The minimal inhibitory concentration (MIC) was defined as the minimal concentration of the compounds which completely inhibited the visible growth of the bacterias. The positive control was chloranphenicol used in the same technique. All assays were tested in duplicate.

\section{Acknowledgments}

The authors thank the Brazilian Agencies for fellowships to WR (PIBIC/CNPq ) and IV (CNPq), and financial support from FUNAPE-UFG. The authors also thank Instituto de Química-UNICAMP for NMR and elemental analyses measurements, and Instituto de FísicaSC/USP for the X-ray single crystal data collection. Silvio Cunha would like to acknowledge his debt of gratitude to Professor Dr. Albert James Kascheres, now retired from Instituto de Química-UNICAMP, for help, advice and guidance in his career.

\section{References}

1. Lue, P.; Greenhill, J. V. In Advances in Heterocyclic Chemistry; Katritzky, A. R., ed.; Academic Press: New York, 1997; Vol 67, p 207.

2. Benovsky, P.; Stepheson, G. A.; Stille, J. R.; J. Am. Chem. Soc 1998, 120, 2493; Cimarelli, C.; Palmieri, G.; Tetrahedron 1998, 54, 915; Desmaële, D.; Mekovar, K.; d’Angelo, J.; J. Org. Chem. 1997, 62, 3890; Murphy, J. P.; Hadden, M.; Stevenson, P. J.; Tetrahedron 1997, 53, 11827; Cook, G. R.; Beholz, L. 
G.; Stille, J. R.; J. Org. Chem. 1994, 59, 3575; Paulvannan, K.; Stille, J. R.; J. Org. Chem. 1994, 59, 1613; Barta, N. S.; Brode, A.; Stille, J. R.; J. Am. Chem. Soc. 1994, 116, 6201.

3. Revial, G.; Lim, S .; Viossat, B.; Lemoine, P.; Tomas, A.; Duprat, A. F.; Pfau, M.; J.Org. Chem. 2000, 65, 4593.

4. d'Angelo, J.; Cavé, C.; Desmaële, D.; Gassama, A.; Thominiaux, C.; Riche, C.; Heterocycles 1998, 47, 725; Hadden, M.; Nieuwenhuyzen, M.; Potts, D.; Stevenson, P. J.; J. Chem. Soc., Perkin Trans. 1 1998, 3437; Furukawa, I.; Ade, T.; Fujisawa, H.; Ohta, T.; Tetrahedron 1997, 53, 17643.

5. Caballero, E.; Madrigal, B.; Medarde, M.; Puebla, P.; Honores, Z.; Martín, E.; Feliciano, A. S.; ACH-Models Chem. 1998, 135, 457; Gupa, A. K.; Ila, H.; Junjappa, H.; Synthesis 1988, 284; Shah, K. R.; Blanton Jr., C. D.; J. Org. Chem. 1982, 47, 502; von Dobeneck, H.; Bruner, E.; Bunker, H.; Metzner, G.; Schmidt, R.; Weil, E.; Sonnenbichler, J.; Liebigs Ann. Chem. 1981, 410; Blanton Jr., C. D.; Whidby, J. F.; Briggs, F. H.; J. Org. Chem. 1971, 36, 3929; Robson, J. H.; Marcus, E.; Chem. Ind. 1971, 1022.

6. Andricopulo, A. D.; Yunes, R. A.; Nunes, R. J.; Savi, A. O. S.; Corrêa, R.; Cruz, A. B.; Cechinel Filho, V.; Quim. Nova 1998 21, 573

7. Cunha, S.; Costa, M. B.; Napolitano, H. B.; Lariucci, C.; Vencato, I.; Tetrahedron 2001, 57, 1671 .
8. Zhuo, J.-C.; Magn. Reson. Chem. 1998, 36, 565.

9. Dewar, M. J. S.; Zoebisch, E. G.; Healy, E. F.; Stewart, J. J. P.; J. Am. Chem. Soc. 1985, 107, 3902.

10. Quantum Chemistry Program Exchange (QCPE), Bloomington, IN, No. 455, 1990, 506.

11. Parr, R. G.; Zhou, Z.; Acc. Chem. Res. 1993, 26, 256; Parr, R. G.; Pearson, R. G.; J. Am. Chem. Soc. 1983, 105, 7512.

12. Kumaraswamy, S.; Kumar, K. S.; Raja, S.; Swamy, K.; Tetrahedron 2001, 57, 8181.

13. Cremer, D.; Pople, J. A.; J. Am. Chem. Soc. 1975, 97, 1354.

14. Braibante, M. E. F.; Braibante, H. S.; Missio, L.; Andricopulo, A.; Synthesis 1994, 898; Braibante, M. E. F.; Braibante, H. S.; Salvatore, S. J. S. A.; Quim. Nova 1990, 13, 67; Rechsteiner, B.; Texier-Boullet, F.; Hamelin, J.; Tetrahedron Lett. 1993, 34, 5071; Ovenden, S. P. B.; Capon, R. J.; Lacey, E.; Gill, J. H.; Friedel, T.; Wadsworth, D.; J. Org. Chem. 1999, 64, 1140; Ramos, J. G.; Barralesrienda, J. M.; Chaves, M. S.; An. Quim. 1977, 139.

15. Sheldrick, G. M.; SHELXS97; Program for the Solution of Crystal Structures; University of Göttingen, Germany, 1990.

16. Sheldrick, G. M; SHELXL97; Program for the Refinement of Crystal Structures; University of Göttingen, Germany, 1997.

17. Alves, S. H.; Cury, A.; Rev. Pat. Trop. 1992 34, 259.

Received: January 6, 2002 Published on the web: August 28, 2002 